bonded by peroxide linkages. A tentative formula was proposed for the crystalline peroxide as

$\mathrm{CH} .\left(\mathrm{CH}_{2}\right)_{3} \cdot \mathrm{CH} . \mathrm{CH}=\mathrm{CH} . \mathrm{CH} \cdot \mathrm{CH}: \mathrm{CH}-$

Dr. O'Neill also described the results of direct studies of the autoxidation of drying oils in film form. Thus linseed oil takes up eight atoms of oxygen per molecule. Some of this oxygen is lost as volatile products, and only five atoms are retained after fourteen days. The volatiles include water, carbon dioxide, aldehydes and acid (particularly formic acid). Little change occurs in the film after a few days, and it seems necessary to postulate scission of the oxidation polymer in order to explain this high oxygen take-up.

C. E. H. BAwN

\section{SCIENCE AND GOVERNMENT}

$\mathrm{I}^{\mathrm{N}}$

his address, "Science and Government", to the American Chemical Society at its meeting in Los Angeles on March 16, Dr. L. A. DuBridge suggested that there are three points of contact between government and science. First, the nature, form and operation of the government determine the political, economic and intellectual climate of a nation, and whether the resulting climate is favourable to science or not may be accidental. If science is to flourish, however, that climate must provide for intellectual freedom, progressive change and the recognition and encouragement of intellectual pursuits. Secondly, science and its technological applications produce changes in the way men live, requiring corresponding changes in the operations, and possibly even in the forms of government. Advances in technology are a major source of advances in human welfare. Thirdly, science and government come together most directly and intimately when science affects matters such as national defence, agriculture, industry, transport, navigation, conservation of natural resources, flood control and the weather, which are prime functions of government.

Following this, Dr. DuBridge reviewed the gradual growth in the United States of government interest in science, from the establishment of the U.S. Coast Survey in 1807 and the creation of the Smithsonian Institution in 1846, until in 1952 Federal Government expenditure on research and development in science and technology was about 1,250 million dollars, or more than 40 per cent of the country's total expenditure on research and development. More significant, however, than this increase in Federal expenditure on research, in Dr. DuBridge's opinion, is the increase in non-Federal research expenditure, from 143 million dollars in 1930 to 1,740 millions in 1952 . Pointing out that it is almost impossible to distinguish rigidly between expenditure on military and non-military purposes, or even between research and development, Dr. DuBridge classified government activities according to five different management techniques commonly used : government agencies under civilian management ; government agencies under military management; government-owned institutions managed privately under contract; contracts for research or development services; and contracts or grants in support of research, usually to colleges or universities.

Dr. DuBridge does not believe that the United States Government is at present getting full value from its vast expenditure on research and development. He thinks that expenditure under the fifth category-research grants--is the most fruitful and valuable. In 1952 this, however, only amounted to about 71 million dollars; and he urged that this should be substantially increased. $\mathrm{He}$ is concerned also that 87 per cent of these funds come from the Atomic Energy Commission and the Department of Defence, whereas, in place of the 15 million dollars requested for basic research by the National Science Foundation, the Foundation has only received 3.25 millions in 1952 and 4.75 millions this year. As regards contracts for research services, Dr. DuBridge repeated the warning frequently given by others, that universities and colleges should be chary of accepting too heavy a load of such sponsored research lest their programmes of basic research be endangered.

The opinion was expressed by Dr. DuBridge that the most successful device for development of new ideas, equipment or techniques for the military services is that of government research centres under private management, such as the Los Alamos Scientific Laboratory operated for the Atomic Energy Commission by the University of California. He believes it desirable that any new research facilities-and as many existing ones as possible-should come under the private management contracts rather than military direction. Apart from proving grounds and acceptance or inspection centres, research centres for new military weapons would be more efficient under civilian direction. It is necessary, moreover, not only to give more attention to planning weapon development expenditure but also to consider problems of grand national strategy against the background of recent scientific and technical developments. For this reason, he suggested the appointment of an outstanding scientist or engineer as scientific adviser to the Defence Department, who might also serve as chairman of the Research and Development Board. The chairman of the Atomic Energy Commission should, in his opinion, be a member of the National Security Council, and that Council should be provided with a science advisory council with a full-time chairman.

\section{U.S. NATIONAL SCIENCE FOUNDATION}

\section{RESEARCH GRANTS}

$\mathrm{D}$

URING the year ended June 30, 1952*, the National Science Foundation made ninety-six grants totalling $1,073,975$ dollars for the support of basic research in the biological, medical, mathematical, physical and engineering sciences at fiftynine institutions in the United States. Research proposals totalling 13.3 million dollars were received, of which 38 per cent were declined, withdrawn or represented reductions in budgets of approved proposals, and 54 per cent are pending. New proposals submitted in 1953 will exceed the 1952 figure, but the limited Foundation funds for research have discouraged many competent investigators from submitting proposals. Those submitted to date have been marked to an unusual extent by originality in

* Sccond Annual Report of the National Science Foundation, Fiscal Year 1952. Pp. vili +77. (Washington, D.C.: Govt. Print. Office, 1953.) 30 cents. 